\title{
Save Energy Now
}

\section{Data Center Assessment Summary} \section{V I
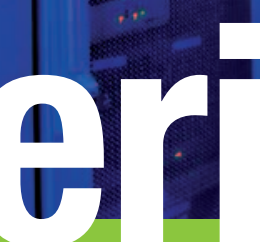 701 \\ DOE Assessment Identifies 30\% Energy Savings for Broadband and Wireless Communication Company}

\section{Company and Data Center Background}

Reducing greenhouse gas emissions and utilizing new, energy-saving technologies are principal environmental objectives for Verizon Communications Inc. In 2008, the company participated in a U.S. Department of Energy (DOE) Industrial Technologies Program energy assessment to examine the energy performance of one of its data centers. The assessment was conducted through Save Energy Now, a national initiative to drive a $25 \%$ reduction in industrial energy intensity in 10 years.

Verizon serves more than 114 million U.S. customers through its various operations, including Verizon Wireless and Verizon Business, which operates more than 200 data centers in 23 countries.

\section{Assessment Process}

Structured primarily as a self-assessment, Verizon staff collected data that was shared with the DOE assessment team during a site visit on February 12-13, 2008. While the assessment revealed opportunities for energy reduction in other areas of the buildings, it focused mainly on the energy-intensive data centers. During the assessment, the team noticed several areas where Verizon already exhibited best practices in computing and data center operation.

The assessment identified numerous opportunities that provide a starting point for Verizon to further investigate ways to save energy in these areas and increase reliability. A majority of the recommendations focused on air management best practices.

The assessment also provided some additional actions the company could take to improve efficiency, such as: adopt a "total cost of ownership" approach to its data centers to help reduce energy use and mitigate rising energy prices; establish an energy manager to monitor energy performance and track improvements over time; replace old equipment; and share best practices with other Verizon data centers.

\section{Energy Efficiency and Renewable Energy}

Bringing you a prosperous future where energy is clean, abundant, reliable, and affordable
Cost Savings

$\$ 181,500$

Energy Savings

Implementation Costs

Payback
1,540,700 kWh $\$ 235,000$ $1.3+$ Years

\section{Data Center At-a-Glance}

- 24,804 square feet

- Receives commercial power from building distribution via a 1,500kVA transformer 13.2kV/480 VAC 3 phase, to two redundant 500KVA uninterruptible power supply (UPS)

- Four building-level chiller plants serve more than 750,000 square feet for cooling

- Cooling demand impacted by seasonal temperatures

\section{Project Drivers}

- Identify opportunities to increase data center efficiency and reliability.

- Improve air management.

- Train Central Plant engineers and technicians about energy efficiency.

- Meet corporate goals to reduce greenhouse gas emissions and deploy new, energy-saving technologies in data center operations.

\section{Recommended Solutions}

- Raise chilled water set point

- Repair water-side economizer

- Install variable frequency drives (VFD) on the condenser water and chilled water pumps

- Increase data center temperature

- Broaden humidity set point

- Improve computer room air handler (CRAH) unit efficiency

- Install lighting controls

- Reduce engine generator heater temperature set point 


\section{Assessment Recommendations}

The following measures identified during the Verizon data center assessment were deemed practical based on estimated implementation costs and payback periods.

\begin{tabular}{|l|l|c|c|c|}
\hline Measure & $\mathbf{k W h / y e a r}$ & $\begin{array}{c}\text { Cost } \\
\text { Savings/ } \\
\text { year }\end{array}$ & $\begin{array}{c}\text { Simple } \\
\text { Capital } \\
\text { Payback }\end{array}$ \\
\hline $\begin{array}{l}\text { Cooling Plant } \\
\text { - Raise chilled water set point } \\
\text { - Repair water-side economizer } \\
\text { - Install VFDs on the condenser } \\
\text { water and chilled water pumps }\end{array}$ & $1,273,300$ & $\$ 150,000$ & $\$ 150,000$ & 1 \\
\hline $\begin{array}{l}\text { Air Management } \\
\text { - Raise data center temperature } \\
\text { - Broaden humidity set point } \\
\text { - Improve CRAH unit efficiency } \\
\text { - Shut down three CRAH units }\end{array}$ & 254,700 & $\$ 30,000$ & $\$ 80,000$ & 2.7 \\
\hline $\begin{array}{l}\text { Electrical System } \\
\text { - Install lighting controls } \\
\text { - Reduce engine generator } \\
\text { heater temperature set point }\end{array}$ & & & & \\
\hline $\begin{array}{r}\text { Total for all measures } \\
\text { (1, }\end{array}$ & $\mathbf{1 , 5 4 0 , 7 0 0}$ & $\mathbf{\$ 1 8 1 , 5 0 0}$ & $\mathbf{\$ 2 3 5 , 0 0 0}$ & \\
\hline
\end{tabular}

\section{Cooling Plant}

- Raise chilled water set point from $42^{\circ} \mathrm{F}$ to $48^{\circ} \mathrm{F}$ to save chiller energy.

- Repair water-side economizer to reduce the chilled water plant power consumption and increase reliability by reducing the wear and tear on the chillers.

- Install VFDs on the condenser water and chilled water pumps to reduce pumping energy and maintenance, and decrease potential points of failure.

\section{Air Management}

- Raise data center temperature set point on the return to the CRAH units until temperatures entering the IT equipment reach the mid- to upper-end of the American Society of Heating, Refrigerating and Air-Conditioning Engineers (ASHRAE) and manufacturer recommended temperature range of $68^{\circ} \mathrm{F}$ to $78^{\circ} \mathrm{F}$.

- Broaden humidity set point to take advantage of the ASHRAE allowable minimum of $20 \%$ humidity, resulting in more efficient cooling coil and chilled water system operation. Additional fan energy savings are also possible but would require converting the computer room air conditioners to include variable speed fans.

- Improve CRAH unit efficiency by adding variable speed fan controls or consider replacing old units with newer, more energy-efficient equipment.

- Shut down three CRAH units as sufficient cooling can still be provided with these units turned off.

\section{Electrical System}

- Install lighting controls to reduce power use when rooms are not occupied (most of the time). Although small in terms of overall data center power use, the controls are relatively easy to implement and savings is compounded through reduction in cooling.

- Reduce engine generator heater temperature set point to $80^{\circ} \mathrm{F}$ (from $140^{\circ} \mathrm{F}$ ). Block heaters for the standby generators should be controlled to only operate when the temperature conditions warrant it.

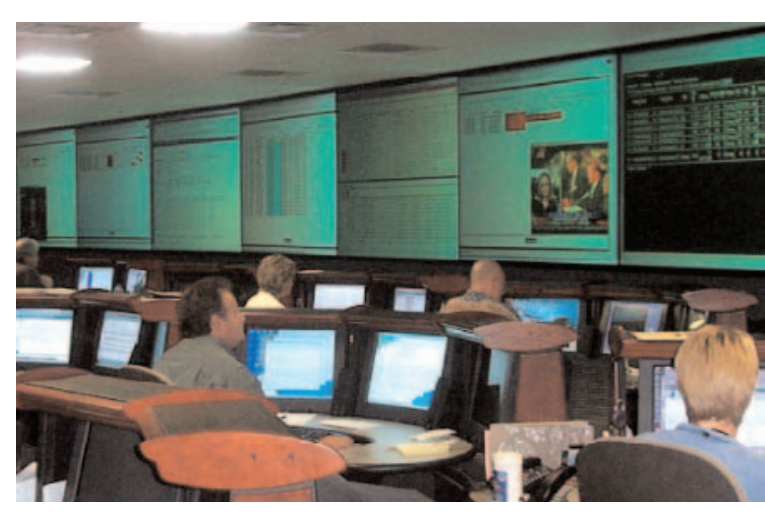

Verizon Business is a leading global communications solutions provider with 32,000 employees and more than 200 data centers in 23 countries.

\section{Save Energy Now in Your Data Center}

Visit the Save Energy Now Data Centers Web site to:

- Learn more about the National Data Center Energy Efficiency Information Program

- Sign up for e-mail updates

- Download the Data Center Energy Profiler (DC Pro) online software tool designed to help companies quickly diagnose how energy is being used by their data centers and ways to save energy and money.

www.eere.energy.gov/datacenters

\section{Public-Private Partnership}

The U.S. Department of Energy's (DOE) Industrial Technologies Program cosponsored the assessment at Verizon to assist in development of industry assessment protocols and tools. Through the Save Energy Now initiative, DOE promotes data center energy efficiency assessments that will lead to improvements in data center efficiency, reliability, and global competitiveness, while reducing environmental impact.

\section{A Strong Energy Portfolio for a Strong America} Energy efficiency and clean, renewable energy will mean a stronger economy, a cleaner environment, and greater energy independence for America. Working with a wide array of state, community, industry, and university partners, the U.S. Department of Energy's Office of Energy Efficiency and Renewable Energy invests in a diverse portfolio of energy technologies.

For additional information, please contact: Industrial Technologies Program www.industry.energy.gov

EERE Information Center

1-877-EERE-INF (1-877-337-3463)

www.eere.energy.gov/informationcenter

DOE/GO-102008-2644

December 2008 